Santa Clara University

Scholar Commons

English

College of Arts \& Sciences

1993

\title{
Loopholes of Resistance: Harriet Jacobs' Slave Narrative and the Critique of Agency in Foucault
}

Michelle Burnham

SantaClara University, mburnham@scu.edu

Follow this and additional works at: http://scholarcommons.scu.edu/engl

Part of the English Language and Literature Commons, and the Feminist, Gender, and Sexuality Studies Commons

\section{Recommended Citation}

Burnham, M. (1193). Loopholes of Resistance: Harriet Jacobs' Slave Narrative and the Critique of Agency in Foucault. Arizona Quarterly: A Journal of American Literature, Culture, and Theory. 49(2). pp. 53-73. 


\section{Loopholes of Resistance: Harriet Jacobs' Slave Narrative and the Critique of Agency in Foucault}

L

OCATED IN THE EXACT CENTER of Harriet Jacobs' I 86r slave narrative, Incidents in the Life of a Slave Girl, is a chapter entitled "The Loophole of Retreat." The chapter's title refers to the tiny crawlspace above her grandmother's shed, where Jacobs hides for seven years in an effort to escape her master's persecution and the "peculiar institution" of slavery which authorizes that persecution. This chapter's central location, whether the result of accident or design, would seem to suggest its structural significance within Jacobs' narrative. Yet its central location is by no means obvious, for "The Loophole of Retreat" goes just as easily unnoticed in the middle of forty-one unnumbered chapters as it becomes - after careful enumeration - potentially quite prominent, as the hinge which balances twenty chapters on either side. It is almost as though this chapter is hidden in plain sight, much like the body of Harriet Jacobs herself, who finally discovers the safest hiding place to be the most obvious one imaginable: in her own grandmother's house and in the center of her master Dr. Flint's domain.

What Jacobs calls her "loophole of retreat" thus provides a strategic site for concealment even as it masks its own location. This spatial loophole becomes for Jacobs a means for escape from slaveiy, and her manipulation of textual loopholes in dominant discourse allows her narrative to escape, as well, from the constraints which her culture necessarily imposes on it. It is this tactical operation of the loophole which I intend to explore not only in Jacobs' narrative but, through her 
text, in the work of Foucault. This loophole operation opens up possibilities for locating and imagining resistance in any discursive structure, including ones which - as Foucault would sometimes have it-effectively exile autonomous agency by producing and then recuperating their own opposition. Critiques of Foucault, including those inspired by Lacanian and pragmatist theory, have all solved this dilemma only by ignoring its very basis: Foucault's important critique of the individual subject as s/he is produced by institutional structures. The figure of the loophole permits a reconfiguration of agency that, unlike the psychoanalytic rescue of agency, accommodates Foucault's critique of the subject and also integrates, rather than elides, the problematic and overlooked category of the structure.

\section{CONFESSION AND CONCEALMENT}

Lydia Maria Child introduces Harriet Jacobs' slave narrative with a gesture of unveiling that promises a subsequent revealing. In her editor's introduction, Child confronts the difficulty of offering to the public Jacobs' account of sexual oppression, by claiming that "this peculiar phase of Slavery has generally been kept veiled; but the public ought to be made acquainted with its monstrous features, and I willingly take the responsibility of presenting them with the veil withdrawn." Child's theatrical, almost voyeuristic, gesture suggests that what will be revealed is not only the body of the desirable female slave, but the truth about that body, and about the Southern institution of slavery that has inscribed it.

A similar language of unveiling proliferates throughout Jacobs' own text, in her recurrent promises "to tell . . . the truth" (53) and to "not try to screen [her]self" from "the painful task of confessing" (54). Jacobs' larger project is to lift the veil of deception that hangs between the North and the South, and it is therefore for her Northern listenerseven those whose "ears are too delicate to listen to" $(4)$ the details of her story - that Jacobs constructs the personal history which was denied her in the South. By confessing the history of her concealed body, she constructs that body as a text for "the women of the North" (I) who, in this sense, function as confessors for Jacobs. Thus her narrative appropriately ends with a statement that suggests on the one hand freedom, and on the other self-display: "when I rode home in the cars I was 
no longer afraid to unveil my face and look at people as they passed" (200; emphasis added).

Clearly, however, the recurrence of such verbs as screening, veiling, and hiding signifies in her text a process of secrecy as much as it does one of exposure. For all its confessional rhetoric, this narrative seems finally far more concerned with that which is hidden, disguised, or kept secret. ${ }^{2}$ Slaves are marked by the lack of a last name and quickly learn to keep the name of the father silent. Slavery is characterized as a condition whose "secrets . . . are concealed like those of the Inquisition" (35), and which actively promotes such deception, for Jacobs claims that "so far as my ways have been crooked, I charge them all upon slavery" ( $\left.{ }_{1} 65\right)$. Slavery enforces secrecy, makes speaking the truth an impossibility, and consigns one's personal history and genealogy to silence. If the North acts as confessor in Harriet Jacobs' narrative, the South plays the role of concealer.

It is perhaps because slavery demands such concealment that slaveowners are so obsessed with what might be kept secret from them. Jacobs first hides from her master when he attempts to visit her during an illness. When he later "demanded to know where I was when he called," Jacobs answers by confessing the truth: "I told him I was at home. He flew into a passion, and said he knew better" (6I). Because the truth is bound to appear to her inquirer so unlikely, Jacobs is able to both confess and keep her secret at the same time. Later, when Jacobs' "grandmother was out of the way he searched every room" (8I) in a futile effort to find the lover he was convinced that his slave was hiding from him. Such anxiety and obsessive suspicion belong not only to Dr. Flint; the preacher Mr. Pike delivers a sermon which accuses the slaves of being "hidden away somewhere" "instead of being engaged in worshipping" (69), and the chapter entitled "Fear of Insurrection," which describes the Southern slaveholders' response to the Nat Turner Rebellion, reveals a search for conspirators so frantic that one of the only safe places for a slave to be was already confined and concealed in jail.

Concealment is thus both what slavery demands and what it fears; concealment produces a reservoir of secrecy that perpetuates slavery but also unsettles it from within. The central act of concealment contained in this confessional text-Jacobs' seven-year confinement in the crawlspace of her grandmother's shed-reveals the potential of that hidden space to empower. A multitude of smaller but similar acts occur 
within this text: Jacobs' grandmother "screened herself in the crowd" (2I) in order to see her captured son Benjamin without his knowledge, the slaveholder Mr. Litch "was so effectively screened by his great wealth that he was called to no account for his crimes" $(46)$, and Jacobs narrowly escaped detection in the shed only because she "slunk down behind a barrel, which entirely screened [her]" (152). Concealmentwhether by crowds, wealth, or barrels - continually marks off in this text a protective space from which one might gaze or act, even if it is only to gaze, like Aunt Marthy, at acts of oppression, or to act, like Mr. Litch, in oppressive ways. It is therefore as necessary to discover such spaces as it is to expose them, generating a process that continually encloses even as it exposes.

This interplay between confession and concealment characterizes, of course, all autobiographies. ${ }^{3}$ Harriet Jacobs' text, however, goes further than most in its continual demonstration that these two operations are mutually implicated in each other, that hiding is always accompanied by exposure, that enclosure always performs an escape. It is this complex relation between concealment and confession that ultimately enables a black feminist agency to operate in Harriet Jacobs' narrative. That double movement structures both her strategy of a quite literal resistance to the oppressions of slavery and patriarchy, as well as a literary strategy of narration that resists a dominant abolitionist discourse which, as Karen Sánchez-Eppler has shown, was largely appropriated by white feminists for political purposes considerably more self-serving than black emancipation. ${ }^{4}$

\section{THE LOOPHOLE AND THE LAW}

If "the loophole of retreat" chapter in Jacobs' Incidents marks and conceals its own importance, then the phrase which makes up its title amplifies that significance through a series of intertextual references. The phrase "the loophole of retreat" originates in William Cowper's I 784 poem The Task, where it designates a site from which "at a safe distance" the poet can protectively observe the extent of the world's woes:

'Tis pleasant through the loop-holes of retreat

To peep at such a world . . . 
Thus sitting, and surveying thus at ease

The globe and its concerns, I seem advanc'd

To some secure and more than mortal height,

That lib'rates and exempts me from them all. ${ }^{5}$

Cowper's hidden loophole is a specifically domestic site-his poem begins by singing, with whatever mock heroism, the praises of a sofa-and the strategic location of that loophole grants him not only a liberatory escape from the world's injustices, but the power of surveillance over those practices.

Because quotations from Cowper's anti-slavery poems often served as epigraphs to chapters in slave narratives or abolitionist fiction, it is quite possible that Jacobs intends a direct reference to Cowper in her chapter title. Yet it is also possible-especially if Jacobs' editor, Lydia Maria Child, influenced or undertook the naming of chapters-that it refers to Child's own use of the phrase in the preface to her 1826 novel Hobomok. Child anonymously writes there in the persona of a reclusive man who "so seldom peep[s] out from the 'loop-holes of retreat' upon a gay and busy world" that he experiences great insecurity about offering his historical novel to the public. Once Child's gender is revealed, as it soon was, the phrase suggests here, too, an explicitly domestic space. ${ }^{6}$ Whether Child or Jacobs generated the title, however, and whatever its external references, the word "loophole" alone involves a set of definitions that elucidate the larger textual strategy of Jacobs' narrative.

According to the Oxford English Dictionary, the first definition of loophole is "[a] narrow vertical opening, usually widening inwards, cut in a wall or other defence, to allow of the passage of missiles." In addition to describing the crawlspace Harriet Jacobs eventually inhabits, this definition's battle imagery perfectly describes the saga of Jacobs' defense of her body against strategic attacks on it by Dr. Flint. She occupies a position that, like the loophole described here, is simultaneously defensive and offensive. Although Jacobs inhabits the descriptively "female" space of the loophole, she deploys from that space the kind of "male" power that one would ordinarily associate with "the passage of missiles." For Jacobs, however, those weapons are not missiles, but the letters (missals?) ${ }^{8}$ addressed to Dr. Flint which she arranges to have postmarked from New York in order to convince him of her escape.

Those letters are one means by which the power relation between master and slave is structurally reversed once Jacobs conceals herself in 
her "loophole of retreat." Jean Fagan Yellin's claim that Jacobs "uses her garret cell as a war room from which to spy on her enemy and to wage psychological warfare against him" (xxviii) both contains the sense of loophole as fortification and suggests the extent to which power has been redistributed between them. Jacobs' powerlessness as a slave is exemplified by Flint's belief that she "was made for his use, made to obey his command in every thing" ( 18 ) and "that she was his property; that [she] must be subject to his will in all things" $(27)$. Whereas Jacobs had formerly been compelled to accept and read the notes with which Dr. Flint persecuted her, from the garret she controls his behavior by compelling him - by way of her letters - to travel North in search of her.

Not only has Jacobs been utterly subject to the command of her master, but she had been the constant object of his gaze as well:

My master met me at every turn, reminding me that I belonged to him, and swearing by heaven and earth that he would compel me to submit to him. If I went out for a breath of fresh air, after a day of unwearied toil, his footsteps dogged me. If I knelt by my mother's grave, his dark shadow fell on me even there.

Jacobs escapes such surveillance only by going into a captivity that in many ways enacts the condition of slavery on a hyperbolic scale. The absence of freedom, the physical hardships, the separation from children and family, and the secrecy that all mark the slave's condition are repeated and exacerbated by Jacobs' confinement "in her dungeon." Yet that repetition is one with a signal difference, a difference that is concealed within the enormity of hyperbole, for "alone in my cell . . . no eye but God's could see me" (133). Not only is Jacobs free from Flint's gaze, but she has appropriated the power of surveillance for herself, since through her "peeping-hole" she is able "to watch the passers by," including Dr. Flint, without being seen, and to "hear many conversations not intended to meet my ears" ( I I 7 ). Jacobs becomes an eyewitness to slavery, a position of spectatorial objectivity which William L. Andrews has argued is usually filled by the abolitionist editors of slave narratives, while the ex-slave authors more commonly serve as the subjective and participatory "I-witnesses" to their own experience. These two positions clearly conflate in Jacobs' text, since she is in the very center of the system of slavery at the same time that she is to some 
degree distantiated from it. ${ }^{9}$ Thus, like Cowper, Jacobs is able to survey "at a safe distance" the "globe and its concerns," and although her space or confinement is far from being conventionally domestic, one of its most important characteristics is that it allows its occupant to survey her children with a protective and disciplinary maternal gaze.

By inhabiting this spatial loophole, Jacobs inadvertently enacts a second definition of the word as "an outlet or means of escape. Often applied to an ambiguity or omission in a statute, etc., which affords opportunity for evading its intention." 10 This sense of the word generally refers to the law, and particularly to written law, where a loophole is not produced so much as it is discovered, and even then it is typically discovered only by accident. Although such escape routes, once detected, are often closed down, by logic every law - no matter how carefully phrased-contains a loophole, since every law contains the permanent possibility of a loophole. A loophole uniquely allows one to transgress the law without actually breaking it, and thus to elude as well any potential punishment for that transgression. Harriet Jacobs' loophole condition is precisely such a simultaneous inscription and transgression of the law of slavery. She is able to reverse the master-slave power relation and to assume a kind of male power only because that reversal and deployment are concealed and contained within the semblance of black enslavement and female powerlessness. Jacobs' relation to that power shift is neither one of conscious premeditation nor one of unconscious passivity. Her unexpected leverage over her master follows solely from her fortuitous habitation in the loophole. Her resultant access to agency is a circumstance of which Jacobs, it seems, becomes only gradually aware, and which she begins only cautiously to exploit.

Both her physical and textual strategies succeed because they mime $^{11}$-sometimes to the point of hyperbole-those systems or discourses which otherwise oppress her. The ironic force of that mimicry discovers loopholes in the structure that escape detection because they are concealed within what appear to remain dominant hierarchies and power relations. Inhabiting those loopholes can transform them into sites of resistance: it is because Harriet Jacobs inhabits a structural site where the practice of power seems so incredibly unlikely that she is able to get away with her resistance to and manipulation of her master. ${ }^{12}$ Thus, by inhabiting a loophole in the first, more spatial, sense of the word as a defensive and enclosed space, Harriet Jacobs enacts the sec- 
ond, more textual, definition of loophole as "a means of escape"; she has discovered and retreated into a loophole in the patriarchal institution of slavery. Although Jacobs' loophole of retreat is the most confining space imaginable, it is finally a space of escape.

\section{SUBJECT AND STRUCTURE}

The operations of concealment and confession that play so critical a role in Harriet Jacobs' narrative of slavery and escape also form the subjects of much of Michel Foucault's work. Foucault's analyses in texts like Discipline and Punish, his study of the birth of the prison system and its normalizing practices of confinement and surveillance, and the first volume of The History of Sexuality, which argues that the confession is a truth-producing practice which generates discourse about sexuality rather than-as psychoanalysis would have it-repressing it, reveal that confession and concealment combine to form a power relation that produces and exposes. The pastoral or criminal confession makes hidden thoughts known, while institutional concealment opens the body and its behavior up to the disciplinary gaze. While Foucault's confessional economy acknowledges a necessary relation between hiding and revealing, wherein "the obligation to conceal [is] but another aspect of the duty to admit," ${ }_{13}$ that economy has been repeatedly criticized for too perfectly reproducing (confessing) all that it consumes (conceals). By the same token, the model of Bentham's panopticon which Foucault uses to define a new disciplinary architecture, in which the subject internalizes the power relation which subjugates her, has been accused of positing a totalizing economy of complete recuperation. New historicist criticism, which has been particularly influenced by Foucault's work on the prison and on sexuality, has in turn generated much critical debate over its use of such models which, the argument goes, deny agency to subjects who are inescapably determined by their historical and cultural context, and who therefore inevitably support and reproduce the dominant power structures they might have set out to resist and subvert. It is not my aim to reproduce that debate here, but rather-through Foucault's own critique of the individualized subject-to shift its terms. Where might one locate the source of that recuperative movement in Foucault's work? Does the panoptic eye in fact see everything, or does 
it have a blind spot? If a confession is a production of truth, does it produce secrets as well?

While her subject is Foucault's influence on film theory rather than in the new historicism, Joan Copjec's Lacanian critique of the panoptic model insists on the subject's capacity for keeping secrets and concealing thought, and thus locates that blind spot in the panoptic theory's disregard of what she calls "the permanent possibility of deception."14 Faulting Foucault for denying repression and thus a split subject, Copjec argues that "the orthopsychic relation (unlike the panoptic one) assumes that it is just this objective survey [which the subject performs on itself] that allows thought to become (not wholly visible, but) secret; it allows thought to remain hidden, even under the most intense scrutiny." 15 Copjec's analysis reveals that because the contents of the unconscious can remain undetectable, the subject can practice deception and thus can always undermine the ideal functioning of the panoptic gaze. Therefore any confession, one assumes, remains incomplete and leaves a residue, forming an imperfect economy with an inevitable degree of waste that is never recuperated. Even as Copjec's solution significantly realizes and includes the possibility of that hidden residue, however, it does not make it at all clear whether or how that might generate a comparable hiding-place for the body, nor how it might enable escape or resistance. Bringing Lacan to the rescue of the Foucauldian panoptic trap springs that trap only to finally re-trap the possibility of agency within the unconscious where it, for all intents and purposes, suffers a kind of paralysis.

That paralysis resembles the very predicament that the psychoanalytic approach set out to solve, a predicament associated with the new historicism and its seemingly irresolvable opposition between independent agency and historical determinism. Anthony Appiah has called that new historicist problematic "structural determinism," 16 and has further suggested that its grounding opposition is based on the mistaken belief that subject and structure are connected categories and that their terms belong to the same discourse. Appiah argues instead that subject and structure represent "two different discursive economies" whose distinction should be recognized and maintained, since "everything that a theory of structure claims to explain belongs to the language, the discourse, of the structure; to insist on autonomous agency within this 
discourse is, if I may say so, simply to change the subject." ${ }^{17}$ Appiah's pragmatic solution therefore is the institution of a complete separation of discourses. As he himself acknowledges, however, such a separation would continue to dissolve in practice, since the impassable gulf he insists exists between subject/structure is continually crossed. Instead of completely disconnecting these two terms from each other, I propose to shift attention toward the space signified by that slash which already (dis)connects them. It is in that juncture where subject and structure meet, rather than in an independent discourse of the subject, that I wish to locate agency. The problem is not, as Appiah suggests, that the independent categories of subject and structure have been falsely wedded, but that the categories of subject and agency have been so.

Perhaps the most consistent, and consistently overlooked, aim of Foucault's own work is to critique and oppose processes that individualize the subject. Despite the fact that Foucault has claimed, for example, that "the political, ethical, social, philosophical problem of our days is not to try to liberate the individual from the state, and from the state's institutions, but to liberate us both from the state and from the type of individualization which is linked to the state," 18 the notion of agency in general, and the one employed by Foucault's critics, remains constructed in terms of the (individual) subject. As a result, and as new historicist criticism reminds us, agency necessarily becomes a form of subjection even as it struggles against subjection. The ongoing critical debate over the problem of agency in Foucault and/or the new historicism therefore often spins in the kind of recuperative circle marked out by this last formulation, and it does so, I am suggesting, because it remains unable to think of agency other than in terms of an autonomous subject working against, rather than within, the structure. The circularity of the subject/structure debate is thus in a sense as much the point of Foucault's work as it is a problem with it. "To change the subject" - to change the meaning of Appiah's phrase-has always been one of the primary aims of Foucault, who has claimed that "we have to promote new forms of subjectivity through the refusal of th[e] kind of individuality which has been imposed on us for several centuries." ${ }_{19}$ Why not refuse, then, the individualization of agency and its entrapment in the discourse of the subject, and posit instead an agency that operates within not only the discourse, but the very architecture of the structure? Only by shifting the conceptualization of agency away from the 
subject and toward the structure might one locate sites that, like loopholes, escape detection and thus enable resistance and agency. This is to argue that, like every law, every structure contains a loophole (since it always contains the possibility of a loophole), regardless of how carefully it is designed-like, for example, a panopticon or slavery-to eliminate the possibility of subversion or escape. ${ }^{20}$ Those seemingly monolithic methods of surveillance that ostensibly make escape from detection impossible may finally enable escape by the very fact that they make it seem so impossible.

Discussions among historians about agency within slavery and black culture reveal a problematic tension between oppression and resistance similar to the one associated with Foucault. Slavery has certainly been characterized as an institution with a disciplinary structure so total that resistance to it was ineffective if not impossible. Stanley Elkins, in his influential book on North American slavery, calls it a "closed system" which prevented rebellion because slaves had no access to standards of judgment or modes of behavior outside of the institution that contained them. Critics of Elkins' thesis resist this monolithic construction by insisting that this closed system in fact contained openings where subversion and sometimes escape could occur. These critiques focus for the most part on the existence of a distinct culture within the slave community which enabled resistance through the residual or emergent alternatives it offered to the dominant culture. ${ }^{21}$ More recently Clarence E. Walker, who has labelled this approach "the slave community/culturalist paradigm," accuses it of "romanticizing" the notion of community and of overestimating the force of an autonomous culture. Walker urges "black history to rise above the romantic and celebratory" by acknowledging the tensions within any oppressed community and by recognizing the extent to which marginal groups internalize dominant culture. ${ }^{22}$ Walker's critique does not specifically address the question of agency, but it is nevertheless an important intervention in a debate which has tended to move in cycles that alternate between foregrounding the psychological and physical damage produced by slavery on the one hand, and the liberating and revisionist potential of black communities within slavery on the other. Walker's project of deromanticization, like Foucault's of deindividualization, explicitly warns against too easily making claims for autonomous resistance and implicitly suggests the need to reformulate conventional constructions of agency. 
The example of Jacobs' text opens the possibility of a model for agency that falls between the culturalist paradigm and its critique, a possibility suggested by the fact that it is able to support both positions. Walker, for example, is able to use Incidents to illustrate that a slave community often did not devalue dominant taboos like illegitimacy, since the pregnant Jacobs fears the censure of her grandmother as much as that of her readers. ${ }^{25}$ At the same time, this narrative clearly serves as an ideal example for those historians intent on asserting the possibility of resistance within slavery. However, Harriet Jacobs' "loophole of retreat" does not so easily fit the culturalist model. Although she enjoys a limited degree of communal support, her hiding place is hardly a space of autonomous culture like the family or religion might be, and it is certainly not a space that can be readily romanticized. Aunt Marthy's garret does not offer a retreat from the oppressive conditions of slavery-as, one might argue, the communal life in Aunt Marthy's house does-so much as it enacts a repetition of them. Because this loophole so resembles that which it opposes, it evades the conceptual opposition between oppression and resistance, as well as the critical opposition between Elkins' "closed system" and the more optimistic emphasis on black community or culture. Harriet Jacobs escapes reigning discourses and structures only in the very process of affirming them. She disobeys social norms of proper motherhood, for example, precisely in order that she might eventually enact those norms. ${ }^{24}$

The example of agency which Harriet Jacobs' slave narrative provides reveals that when Foucault announces the arrival of "a panopticism in which the vigilance of intersecting gazes was soon to render useless both the eagle and the sun, "25 he fails to consider that panopticism carries within it the inevitable blind spot associated with its predecessors; the loophole, both as hiding-place and as escape route, is that blind spot, and it is in that blind spot that secrets reside and through which bodies may escape. The paralytic circularity of the subject/structure debate can be avoided by relocating agency in the juncture between the structure and the subject, in sites that elude the gaze not because they are outside the structure (or distinct from its culture) but because they are so clearly and centrally a part of it. Harriet Jacobs inhabits such a fissure in the very architecture of the "patriarchal institution'" ( 146 ) - a structure that she has already ironized by means of framing quotation marks - and that fissure eludes Dr. Flint's searching 
gaze because it is located directly in front of that gaze. The loophole is in this sense akin to the sites of feminist agency posited by Teresa de Lauretis as "the elsewhere of discourse here and now, the blind spots, or the space-off, of its representations. I think of it as spaces in the margins of hegemonic discourses, social spaces carved in the interstices of institutions and in the chinks and cracks of the power/knowledge apparati": ${ }^{26}$ patriarchy's space-off, Dr. Flint's blind spot, the loophole of retreat. The garret of the shed beside Harriet Jacobs' grandmother's house was the least likely place of escape because it was from the beginning the most likely place of concealment: "it was the last place they thought of. Yet there was no place, where slavery existed, that could have afforded me so good a place of concealment" (I I 7 ).

\section{SENTIMENTALITY AND SLAVERY}

In her struggle against slavery and patriarchy, one might claim that Harriet Jacobs practices a kind of camouflage, since she hides by miming the confinement and suffering that characterize those very conditions against which she battles. ${ }^{27}$ Jacobs' physical strategy of escape and her narrative strategy of protest are finally quite alike in their inadvertent but fortuitous use of camouflage. While Jacobs' body is inscribed by the law of slavery, through the figure of the loophole she simultaneously transgresses, even as she embodies, that law. I would argue that Jacobs' use of the sentimental discourse prevalent in popular women's novels of nineteenth-century America ${ }^{28}$ operates by a similarly double movement. Just as her hyperbolic miming of the condition of slavery produces a rupture that her body can inhabit, and from which a feminist agency can operate, her employment of sentimental discourse, associated especially with the fiction of white feminist-abolitionists, opens loopholes within that discourse that allow her to critique it. ${ }^{29}$

Jacobs clearly employs the strategies and structures of sentimental fiction throughout her narrative in an effort to inspire her Northern female readers to respond emotionally to her story and to translate that emotion into moral behavior. The similarities, for example, between her text and Samuel Richardson's Pamela suggest the extent to which Jacobs may have consciously borrowed from that genre. ${ }^{30}$ Conscious borrowing, however, was hardly necessary, since in mid-nineteenthcentury America both women's writing and abolitionist writing were in 
large part characterized by sentimentality. Such writing appealed to a reader's sympathy by portraying scenes of often theatrical pathos, and by constructing plots of familial separation and individual trial. This sympathetic readerly response, often marked by the physical response of tears, ideally translated into political action, especially in the case of abolitionist fiction. Thus the aim of such fiction is to convert passivity into activity, to transform the objective response of "being moved by" the text into the subjective action of "moving."

There are, of course, several places where Jacobs reveals significant disjunctions between standard sentimental plots and the facts of her own life. Those moments include her decision to take a lover, the birth of her two children out of wedlock, and the impossibility of her story ending in marriage-differences that lead Jacobs to suggest that "the slave woman ought not to be judged by the same standard as others" (56). William L. Andrews has argued that interstitial or liminal narrators like Jacobs were able to fashion new versions of self by virtue of their "betwixt and between" positions. ${ }^{32}$ Thus it is the disjunction between the cultural ideal embodied in the cult of true womanhood and the impossibility that Jacobs could ever conform to such an ideal that leads her to suggest the need for an alternate standard for the slave women.

Such revisions of the conventional sentimental narrative, however, signal less significant moments in Jacobs' text than those in which she stages an outright condemnation of sentimentalism. By far the most bitingly ironic depiction of sentiment is Mrs. Flint's response to the death of aunt Nancy. Jacobs writes that "Mrs. Flint had rendered her poor foster-sister childless, apparently without compunction; and with cruel selfishness had ruined her health by years of incessant, unrequited toil, and broken rest. But now she became very sentimntal." The worst effect of such displays like the grand funeral, at which "the mistress dropped a tear, and returned to her carriage, probably thinking she had performed her duty nobly," is that

Northern travellers, passing through the place, might have described this tribute of respect to the humble dead as a beautiful feature in the "patriarchal institution"; a touching proof of the attachment between slaveholders and their servants; and tender-hearted Mrs. Flint would have confirmed this impression, with handkerchief at her eyes. (146) 
Jacobs' intent, in exposing Mrs. Flint's performance, is therefore to unveil such sentimentality's deception of the North, to reveal that which sentimentality conceals. She manipulates a similar unveiling, with similar irony, when she includes the highly sentimental letter written by Dr. Flint to her in New York. Pretending to write as his own son, Flint tells Jacobs that he "sympathize[s] with you in your unfortunate condition," promises to "receive you with open arms and tears of joy" (I 7 I ), and describes the death of her aunt as someone who

taught us how to live-and, $\mathrm{O}$, too high the price of knowledge, she taught us how to die! Could you have seen us round her death bed, with her mother, all mingling our tears in one common stream, you would have thought the same heartfelt tie existed between a master and his servant, as between a mother and her child. ( 172 )

Despite Jacobs' use of sentimental discourse throughout her narrative, in these two instances Jacobs attacks sentimentality as deceptive, as a discursive technique that hides rather than confesses the truth. Such an offensive against sentimentality from within sentimentality resembles Harriet Jacobs' strategy of escape from slavery by miming its condition.

The movement of sentimentality in this text is like the movement of the loophole, which inscribes that which it simultaneously transgresses. That double action constitutes, I suggest, a fundamental property of sentimental discourse, which employs the very tactics it attempts to argue against, and whose politics therefore seem to be so easily recuperated. The politics of sentimentality have always, it seems, been caught in a debate between those who see it as a legitimately liberating discourse that gives women access to a revisionist economic and political power, and those who see it as a rationalization of dominant orders that deny women power. ${ }^{33}$ Even those sentimental texts which, like Uncle Tom's Cabin, most overtly criticize existing relations are subject to readings that emphasize instead their reactionary effects. As a result of this fundamental political ambiguity, conventional and radical claims are frequently made for the same narrative. The miming strategy that underlies Harriet Jacobs' conflict with a master who oppresses her and with a sentimental discourse that marginalizes her reveals in its double movement the source of that ambiguity. Sentimental fiction is politically subversive, it would seem, only to the extent that it appears to be 
politically conservative. Such a strategy necessarily generates both reactionary and radical reading effects. It is the action of such a contradiction, however, that uncovers loopholes, loopholes which-as we have seen-can become autonomous feminist, and black feminist, sites of agency. Confession conceals as much as it reveals; it constructs veils in the very gesture of unveiling.

That play between concealing and revealing secrets structures the very functioning of sentimental discourse, which typically claims tears as a mark of its success. Those tears are not, as one might imagine and as the texts themselves suggest, a sign of the catharsis of complete confession, but a sign rather of confession's inevitable incompleteness; it is as though the tears that are secreted (in the sense of produced) substitute for, and serve as a sign of, that which remains secreted (in its other sense as hidden). Perhaps the most pathetic moment in her narrative, for example, is when Harriet Jacobs' son runs, covered with blood from being attacked by a dog, past her hiding-place. Her inability to comfort or even speak to him produces a tearful moment. The reader's sentimental response occurs when Jacobs' desire to confess-to reveal the secret of her location in the "loophole of retreat"-is repressed and she is forced instead, like the reader, to endure the suffering of passive spectatorship. That pathos is generated in the disjunction between what is confessed and what is concealed, and the structural interstices that result from such disjunctions are sites that enable agency.

Harriet Jacobs' immediate political goal of encouraging her readers to resist the Fugitive Slave Law points out a loophole in that law which, too, provides access to agency. Since Northerners were expected to report runaway slaves so that they might be returned to their Southern owners, this law was unusual in that it required rather than forbade action in order to be obeyed. As a result, by simply remaining passive and silent, it was possible to transgress and resist the Fugitive Slave Law without actually breaking it. One might claim that such passivity mimics Northern abolitionists' failure to actively oppose slavery, particularly since the North's capture and execution of the radical antislavery activist John Brown occurred not long before the publication of Incidents. Given the camouflage effect of mimicry, detection of such resistance by passivity would be virtually impossible.

The absence of Harriet Jacobs' final chapter on the John Brown incident from her published narrative suggests that even Lydia Maria 
Child's opening promise of confession and unveiling practices its own concealment. Child, in fact, advised Jacobs to excise that last chapter and to add instead an internal chapter on the Southern response to the Nat Turner Rebellion. ${ }^{34}$ Though Child's advice may have been artistic or financial-encouraging greater aesthetic cohesion or better salesrather than political, its effect is nevertheless to end Incidents in the Life of a Slave Girl, as Jean Fagan Yellin has pointed out, on a personal and sentimental rather than a public and political note. ${ }^{35}$ Thus this text's ending conceals another one, and the chapter added in its stead suggestively portrays the obsessive anxiety among Southern whites about what might be concealed from them. In that added chapter, marauders search through Jacobs' grandmother's house for secrets. All they uncover, however, are letters which, Jacobs explains to them, "'are from white people. Some request me to burn them after they are read, and some I destroy without reading'" (66). Lydia Maria Child and Harriet Jacobs present this narrative to the North as a true and complete confession from an escaped female slave. Yet that supplementary chapter and its unread letters stand as one sign, perhaps, of the North's suppression of a different kind of historical and political consciousness in this text. State University of New York at Buffalo

\section{NOTES}

I. Harriet A. Jacobs, Incidents in the Life of a Slave Girl, ed. Lydia Maria Child, ed. and intro. Jean Fagan Yellin (Cambridge: Harvard University Press, i987) 4; emphasis added. All citations from Jacobs' narrative, unless otherwise noted, will refer to this edition and will appear within parentheses.

2. Joanne Braxton has pointed to Jacobs' many uses of disguise and concealment, including keeping her literacy, her pregnancy, her love for a black man, and the identity of her white lover secret, in "Harriet Jacobs' Incidents in the Life of a Slave Girl: The Re-Definition of the Slave Narrative Genre," Massachusetts Review 27.2 (1986): 379-87.

3. Elizabeth Fox-Genovese has suggested that this tension "between exhibitionism and secrecy, between self-display and self-concealment" ( I66) may be especially marked in the autobiographies of African-American women. "To Write My Self: The Autobiographies of Afro-American Women," Feminist Issues in Literary Scholarship, ed. Shari Benstock (Bloomington: Indiana University Press, 1987): I $6 \mathrm{I}-80$.

4. Karen Sánchez-Eppler, "Bodily Bonds: The Intersecting Rhetorics of Feminism and Abolition," Representations 24 ( 1988 ): 28-59. 
5. William Cowper, "The Task," The Poetical Works of William Cowper, 3rd ed., ed. H. S. Milford (London: Oxford University Press, 1926) I 84.

6. Lydia Maria Child, Hobomok and Other Writings on Indians, ed. Carolyn L. Karcher (New Brunswick: Rutgers University Press, 1986) 4. The domestic space to which both Cowper and Child refer is one with which Harriet Jacobs' white middle-class female readership would have been able to identify.

7. "Loophole," Oxford English Dictionary, I97I ed.

8. A "missal," in addition to a prayer book, is an obsolete variant of "missile" according to the OED. In a slight twist on the Derridean postal system in which letters always potentially fail to arrive at their destination, these letters successfully reach their addressee only to utterly misrepresent their origin and sender. Alan Bass' glossary suggests the fascinating possibility of an association between the postal system and the loophole in his analysis of the term trier, which

. . . means "to sort," especially in the postal sense of sorting letters for distribution. . . . The false link between sorting and death is contained in the word meutrière, which means both murderess, and the vertical slot in a fortress wall through which one can project weapons [that is, a loophole]." (xxviii, emphasis added)

See Alan Bass, "Translator's Introduction: L Before K," The Post Card: From Socrates to Freud and Beyond, by Jacques Derrida, trans. Alan Bass (Chicago: University of Chicago Press, 1987) ix-xxx.

9. William L. Andrews, To Tell A Free Story: The First Century of Afro-American Autobiography, I760-1865 (Urbana: University of Illinois Press, I986) 65. According to Andrews, abolitionist editors privileged objectivity in order to substantiate a narrative's truth value, which was measured by the distance between the "I" and the "eye" (63). It is no doubt because that distance is minimized in Incidents that it has taken readers so long to accept its authenticity.

10. "Loophole," Oxford English Dictionary, i97 I ed.

I I. I am using mime here in the sense which Luce Irigaray gives it as a feminist strategy in which "one must assume the feminine role deliberately. Which means already to convert a form of subordination into an affirmation, and thus to begin to thwart it. . . . To play with mimesis is thus, for a woman, to try to recover the place of her exploitation by discourse, without allowing herself to be simply reduced to it" $(76)$. This Sex Which Is Not One, trans. Catherine Porter (Ithaca: Cornell University Press, 1985).

I 2. This arrangement is roughly analogous to Nancy Armstrong's reading of domestic novels and the Victorian domestic sphere, where female power is able to operate precisely because it is hidden in the home, where its operation is so unlikely. However, the link between such a textual strategy of camouflage and subsequent social empowerment or escape is far more obvious in Jacobs' narrative than in any of the domestic novels Armstrong reads, where it is unclear how their readers' "fantasies of political power" (29) extended beyond their status as fantasies. Desire and Domestic Fiction: A Political History of the Novel (Oxford: Oxford University Press, 1987). 
13. Michel Foucault, The History of Sexuality, Volume I: An Introduction (New York: Vintage Books, I980) $6 \mathbf{I}$.

14. Joan Copjec, "The Orthopsychic Subject: Film Theory and the Reception of Lacan," October 49 (1989): 65.

15. Copjec 63.

16. Anthony Appiah, "Tolerable Falsehoods: Agency and the Interests of Theory," in The Consequences of Theory, ed. Jonathan Arac and Barbara Johnson (Baltimore: Johns Hopkins University Press, I990) 66.

17. Appiah 79, 84 .

18. Michel Foucault, "The Subject and Power," in Hubert L. Dreyfus and Paul Rabinow, Michel Foucault: Beyond Structuralism and Hermeneutics, and ed. (Chicago: University of Chicago Press, 1983) 216.

19. Foucault, "The Subject and Power" 216.

20. In fact, and almost as though to prove the point, Bentham's original panopticon design contained its own inadvertent loophole. As Alan Liu has noted, "Bentham's totalitarian vision . . . had a loophole," for "Bentham discovered after drawing up his plans that a blank space had inadvertently been left in the central tower in the area of the chapel" (103). Liu's short and limited discussion of that space focuses on the vision of the tourists with whom Bentham proposed to fill the space, rather than on the implications that empty space might have for the inmates themselves. See Liu's Wordsworth: The Sense of History (Stanford: Stanford University Press, I989).

21. Stanley M. Elkins, Slavery: A Problem in American Institutional and Intellectual Life, 3rd ed., rev. (Chicago: University of Chicago Press, 1976); Ann J. Lane, ed., The Debate over Slavery: Stanley Elkins and His Critics (Urbana: University of Illinois Press, 1971).

22. Clarence E. Walker, Deromanticizing Black History: Critical Essays and Reappraisals (Knoxville: University of Tennessee Press, I99I) xviii. Walker's larger agenda is to urge a shift away from class-oriented Marxist analyses of race relations in nineteenth-century America and toward a theoretical model that would not conflate race with or reduce it to economic categories.

23. Walker xvii.

24. William L. Andrews has similarly argued that the spiritual autobiographies of black women justify their transgression of cultural conventions against women preachers only by invoking and obeying theological conventions such as sanctification. Andrews, ed., Sisters of the Spirit: Three Black Women's Autobiographies of the Nineteenth Century (Bloomington: Indiana University Press, 1986) I6.

25. Michel Foucault, Discipline and Punish: The Birth of the Prison (New York: Vintage Books, I 979) 2 I 7.

26. Teresa de Lauretis, Technologies of Gender: Essays on Theory, Film, and Fiction (Bloomington: Indiana University Press, 1987) 25.

27. Lacan makes precisely such a connection between mimicry and camouflage when he writes that "the effect of mimicry is camouflage in the strictly technical sense. It is not a question of harmonizing with the background, but against a mottled background, of becoming mottled-exactly like the technique of camou- 
flage practiced in human warfare" (99). Jacques Lacan, The Four Fundamental Concepts of Psychoanalysis, ed. Jacques-Alain Miller, trans. Alan Sheridan (New York: Norton, 1971).

28. Harriet Beecher Stowe, Susan Warner, Maria Cummins, and Catherine Maria Sedgwick are among the best known, and were among the most popular, of these sentimental novelists. Their work makes up what Lauren Berlant has called an "American female culture industry" that had enormous economic success on the print market in nineteenth-century America, as well as a substantial cultural impact on its readership. See Lauren Berlant, "The Female Woman: Fanny Fern and the Form of Sentiment," American Literary History 3 ( I991): 429-54.

29. Valerie Smith identifies in Jacobs' narrative "linguistic spaces-verbal equivalents analogous to the garret in which she hides" (xxxiii) that are similar in conception to my notion of a textual or discursive loophole. Smith's focus, however, is on Jacobs' revision of the male slave narrative and the sentimental novel, while I am emphasizing Jacobs' far more tactical attack on the latter. Valerie Smith, "Introduction," Incidents in the Life of a Slave Girl, by Harriet Jacobs (New York: Oxford University Press, 1988).

30. Valerie Smith notes the similarity between Harriet Jacobs' story and Samuel Richardson's novel (xxxi-ii). It is especially striking that Flint, like Mr. B., seems as obsessed with obtaining his servant's consent as he is with achieving her seduction.

31. The definition of sentimentality with which I am working here is one which insists on a certain readerly response - that is, sympathy, pity, tears, and the potential transformation of such emotion into political action or social changeachieved through a stylized use of language and of a narrative structure based largely on deferred agnition. Therefore it is the affective similarity between such disparate works as Pamela and Uncle Tom's Cabin, rather than their historical and cultural differences, that I emphasize. Such a definition necessarily leaves out those "sentimental" novels whose affective sincerity is erased or undercut by a critical ironythe eighteenth-century English novels of Sterne or Goldsmith, for example. Whether the reader's emotional response does in fact translate into political action is another, highly debatable, question. The tears which respond to scenes of injustice are just as likely to blur those scenes.

32. Andrews, To Tell a Free Story $175,203$.

33. Though the use of sentimentality is by no means limited to female writers and feminocentric plots, discussions of the politics of sentimentality are generally, and curiously, limited to just such texts. Karen Sánchez-Eppler, in her essay "Bodily Bonds," convincingly demonstrates that feminist-abolitionist discourse in its sentimental mode appropriates and bleaches the body of the black slave in its represention of slavery as sexual oppression, thus constructing images and plots with which white feminist writers and readers could identify. Ann Douglas insists that sentimental fiction supports the developing capitalist system in The Feminization of American Culture (New York: Alfred A. Knopf, 1977), while Jane Tompkins and Gillian Brown claim, respectively, that sentimental fiction stages a critique of traditional economic and domestic orders. See Tompkins' Sensational Designs: The Cultural Work of American Fiction, I 780-r 860 (New York: Oxford University Press, 1985), 
and Brown's Domestic Individualism: Imagining Self in Nineteenth-Century America (Berkeley: University of California Press, 1990).

34. For more background on this editorial change see Bruce Mills, "Lydia Maria Child and the Endings to Harriet Jacobs' Incidents in the Life of a Slave Girl," American Literature 64 (1992): 255-72.

35. Yellin xxii.

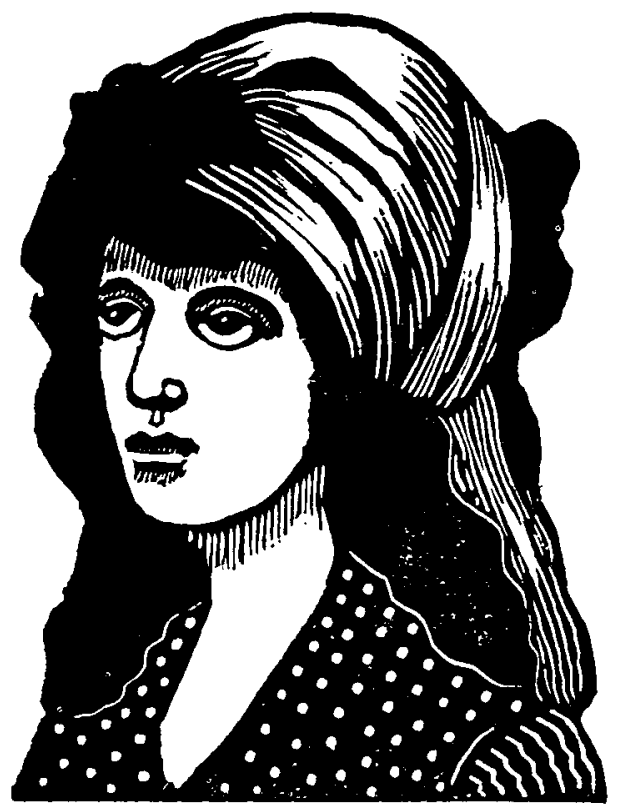

